\title{
The impact of ISP, BPR, and customization on ERP performance in manufacturing SMEs of Korea
}

Soon-Goo Hong

Department of Management Information Systems, Dong-A University, Busan, South Korea

Keng Siau

Missouri University of Science and Technology, Rolla, Missouri, USA, and Jong-Weon Kim

Department of Management Information Systems, Dong-Eui University, Busan, South Korea

\begin{abstract}
Purpose - This paper aims to assess how enterprise resource planning (ERP) performance of Korean small and medium enterprises in manufacturing differs according to different levels of business process reengineering (BPR), information strategic planning (ISP) and ERP customization.

Design/methodology/approach - A questionnaire survey was carried out in this research. Responses from 96 small and medium manufacturing companies that have adopted ERP systems were analyzed.

Findings - The results of this study suggest that ISP and BPR implementation are positively correlated to ERP performance.

Originality/value - While consulting and customization costs have positive impacts on ERP performance, the level of customization does not influence performance. As one of the pioneering studies that investigate the impact of BPR, ISP and ERP customization on small and medium manufacturing companies, this research contributes to both theory and practice.
\end{abstract}

Keywords Enterprise resource planning (ERP), Small medium-sized enterprises, Information strategic planning (ISP), Business process reengineering (BPR),

Balanced score card (BSC)

Paper type Research paper

(C) Jong-Weon Kim, Soon-Goo Hong and Keng Siau. Published in the Asia Pacific Journal of Innovation and Entrepreneurship. This article is published under the Creative Commons Attribution (CC BY 4.0) licence. Anyone may reproduce, distribute, translate and create derivative works of this article (for both commercial and non-commercial purposes), subject to full attribution to the original publication and authors. The full terms of this licence may be seen at: http://creativecommons.org/licences/by/4.0/legalcode

This work was supported by the Dong-A University research fund.

Received 1 August 2016 Revised 25 September 2016 Accepted 28 September 2016 


\section{Introduction}

Enterprise resource planning (ERP) is defined as a company-wide information system that incorporates major business functions such as accounting, human resources management, production and marketing. Introducing ERP allows companies to enjoy financial and non-financial benefits, including inventory reduction, data integration and cost reduction (Jin et al., 2012; Lee et al., 2003; Holsapple and Sena, 2005; Gefen and Ragowsky, 2005; Aloini et al., 2007; Nah et al., 2007; Sammon and Adam, 2010). Initially used for internal integration, ERP is now applied toward external integration with management executive systems and supply chain management. In fact, ERP is increasingly being recognized as a business strategy tool for improving corporate competitiveness, and more and more small- and medium-sized manufacturers have been adopting ERP systems (Choi et al., 2013).

Numerous studies have examined the impact of ERP implementation on business performance (Choi et al., 2011; Pairin et al., 2006; Liang and Xue, 2004; Lin et al., 2006). However, most studies have targeted large enterprises, while ERP performance in small and medium enterprises (SMEs) is rarely taken into consideration. Prior research results showed that SMEs are not merely scaled-down versions of large businesses, and thus, management theories for large companies cannot be applied to SMEs (Deo, 2010; Lee et al., 2014; Park et al., 2012; Schubert et al., 2006; Thong et al., 1996; Yun and Jung, 2013). In the same vein, studies on ERP implementation in large businesses cannot be directly applied to SMEs. According to the results of Korean manufacturing firms surveyed by Pairin et al. (2006), most SME manufacturers apply the market-to-order (MTO) method to produce a wide range of products in small volume and thereby deal successfully with downward pressure on costs in the ever-globalized business environment. Thus, SMEs have developed unique business processes compared to those of large businesses, and these distinct characteristics need to be taken into account for ERP performance measurement. In the case of these SME manufacturers, limited financial resources obstruct decision-making about whether to push for business process reengineering (BPR) and information strategic planning (ISP), which are considered key success factors of ERP implementation (Kohli and Hoadley, 2006; Larsen and Myers, 1999; Muscatelli et al., 2003; Bernroider, 2008; Aloini et al., 2007).

In addition, embedded in ERP packages are well-established best practices, and accordingly, companies can improve their processes by adopting such packages. The result of previous studies (Light, 2001) showed that, however, the efficacy of ERP implementation may be undermined if ERP packages are largely customized to the respective processes of businesses. BPR and ISP may be necessary to bring out the benefits of ERP. This is an important research question because ERP implementations are typically very costly and time-consuming. Unless the organizations can fully capitalize on the benefits of ERP, ERP implementations may be a waste of time and resources. This study addresses this important research question by studying whether the ERP performance of Korean SME manufacturers is different according to the BPR and ISP implementation and levels of ERP customization.

\section{Literature review on measuring ERP performance}

Various studies have been carried out to ensure successful ERP implementations. The major areas of research regarding successful ERP are divided into two categories: critical success or failure factors and ERP performance measurement. The former, 
which initially focused on large companies, has expanded to focus on SMEs (Costa and Gianecchini, 2006; Buonanno et al., 2005). Studies on major success factors have useful implications for ERP implementation problems (Liang and Xue, 2004) and provided practitioners with guidelines for successful ERP implementations. In addition, Kim and Park (2006) investigate if BPR has a moderator effect on ERP performance in Korea SMEs. With the analysis of 77 valid questionnaires, they concluded that BPR is the most important factor for ERP success.

DeLone and McLean's $(1992,2003)$ information system (IS) success model is widely ERP performance in manufacturing SMEs used as the methodology for measuring ERP performance (Bernroider, 2008). This model is useful in identifying a wide variety of independent variables constituting success factors from previous studies, examining the associations between these independent variables and parameters (e.g. information quality, system quality and user satisfaction/usage) and verifying their relationships with ERP performance (e.g. individual, group and corporate performance). Meanwhile, other studies have measured ERP performance using Kaplan and Norton's (1992) balanced score card (BSC) model. For instance, Hong et al. (2005) measured the ERP performance of manufacturers based on the BSC, and Lin et al. (2006) proposed an ERP performance measurement framework that incorporates the IS success model and the BSC model.

When one thinks of performance, the variable that comes to mind is typically financial measurement. Kaplan and Norton (1992) argued that conventional methodologies for performance measurement leaned too much toward financial measurement. They proposed the $\mathrm{BSC}$, which consists of the following four variables: financial perspective, customer perspective, internal process perspective and learning/growth perspective. First, the goal of financial perspective - creation of long-term profits - is the same as what has been aimed at in conventional performance measurement systems. This perspective is associated with the goals of other perspectives in the BSC model (i.e. customer, internal process and learning/ growth). In other words, financial performance is the result of the other three aspects of BSC. Second, customers are the source of profits from the viewpoint of businesses, so performance indices from the customer perspective basically involve whether customers are provided with the results and services they desire, and whether they are satisfied with the services. This can be summarized as a single question: "Has ERP adoption improved your customer relations?". Third, satisfying customers requires efficient internal management of business procedures and the decision-making process and well-organized internal processes. In this regard, the internal process perspective is closely associated with BPR. Fourth, the learning/ growth perspective constitutes an infrastructure for realizing the goals of financial, customer and internal process perspectives. This includes laying the groundwork for better performance, providing training sessions for employees and building an information system to offer necessary information in a timely manner.

According to the research result by Garengo et al. (2005), studies on performance measurement after the mid-1980s are oriented to be more balanced, and this approach is also important to SMEs that usually focused on single aspects in performance measurement. In addition, Rosemann (1999) pointed out that a BSC is a good tool for ERP measurement for the following reasons:

- "balanced Scorecards are typically designed to monitor business processes"; and

- "balanced Scorecard is the consistent transformation of visions into strategies, objective and measures". 
Thus, in this study, we adopted some of the BSC variables in measuring ERP performance.

\section{Research hypotheses}

\subsection{Hypotheses on ISP implementation and ERP performance}

To ensure a successful ERP implementation, a company's purpose for adopting ERP should be aligned with the company's business strategies. The fit between ERP and organizational strategy is often considered essential to achieving gains in organizational performance (Muscatello et al., 2003; Irani and Love, 2008; Kotha and Swamidass, 2000). For instance, a study on Finnish companies found that there was a positive relationship between the alignment of ERP implementation and business strategies, and ERP success (Velcu, 2007).

The concept of ISP was first created by IBM as a methodology called business system planning to enable information systems to effectively support business strategies. ISP is a master plan that analyzes an enterprise's needs for information technology from a macroscopic perspective, fitting the enterprises strategies on a phase-by-phase basis. ISP is carried out generally for the following two objectives:

(1) alignment between a company's strategy and information strategy, through which user-oriented plans are formulated and the priorities for information system implementation are set; and

(2) development of a framework for an integrated information system ensuring internal information sharing, which allows the company to build an information system and encourages the participation of end-users to lay a foundation for greater user confidence in future information systems.

Therefore, by carrying out ISP upon or before ERP adoption, the need for ERP - especially for achieving long-term business goals - can be further emphasized to end-users, resulting in positive ERP performance. To this end, the following hypotheses are established:

H1-1. SME manufacturers performing ISP before or upon ERP implementation will show better financial performance than those that do not.

H1-2. SME manufacturers performing ISP before or upon ERP implementation will show better customer performance than those that do not.

H1-3. SME manufacturers performing ISP before or upon ERP implementation will show better internal process performance than those that do not.

\subsection{Hypotheses on BPR implementation and ERP performance}

Analysis of overall processes is a must for ERP implementation because ERP focuses on building an integrated system encompassing sales, human resources management, production and marketing (Muscatello et al., 2003). Accordingly, ERP requires improvement of entire processes from customers' perspectives, and thus, analyzing a business's overall processes and collecting the necessary information are essential for successful adoption of ERP. Many previous research results (Schniederjans and Kim, 2005; Lee et al., 2008; Ansari, 2000) have claimed that BPR is essential for successful implementation of ERP. A pioneer in the field of BPR, Hammer (1999) highlighted the importance of BPR upon implementing ERP as follows: "A successful ERP implementation must be managed as a program of wide-ranging organizational change 
rather than as a software installation effort". In the same vein, major failure factors of ERP include a lack of planning and restructuring before ERP adoption (Schniederjans and Kim, 2005). BPR provides a preview of problem-prone areas and pushes for organizational restructuring in advance, contributing greatly to the successful adoption of ERP (Ansari, 2000; Elzinga et al., 1999; Sethi and King, 1998).

Given the characteristics of SME manufacturers in Korea, it is extremely difficult to revolutionize their business processes. Martinsons (2004) argued that cultural, economic and political aspects need to be considered in altering business processes, and corporate culture is the most important factor, especially in the case of Asian countries. BPR pushes for radical change in business processes, which may lead to an adverse reaction from employees who are familiar with conventional business processes. For example, as the conventional, hierarchical decision-making structure is replaced by a flat structure, resistance from employees who formerly had decision-making authority may cause the ERP implementation to fail (Martinsons, 2004). O'Leary (2000) pointed out that, due to such differences in corporate culture, more Chinese businesses leave out BRP, while their Western counterparts generally carry out BPR upon ERP implementation. Jang et al. (2000) used an e-mail/fax-based survey to identify the critical success factors, including BPR for ERP implementation. Pearson correlation and $t$-test analyses on 137 valid questionnaires were performed, and it was found that BPR implementation had a positive association with ERP performance. Based on these previous studies, the following hypotheses are proposed:

H2-1. SME manufacturers performing BPR before or upon ERP implementation will show better financial performance than those that do not.

H2-2. SME manufacturers performing BPR before or upon ERP implementation will show better customer performance than those that do not.

H2-3. SME manufacturers performing BPR before or upon ERP implementation will show better internal process performance than those that do not.

\subsection{Hypotheses on customization levels and ERP performance}

ERP packages benchmark the business processes of exemplary leading organizations as best practices, and thus, organizations should improve their processes as much as possible in accordance with suggestions in the ERP packages. Theoretically, BPR can be automatically implemented when companies' business processes are modified in accordance with those embedded in the ERP packages. After purchasing an ERP package, the company needs to tailor this package to meet the company's current business processes, which is called the configuration process (Markus et al., 1999). This means companies need to decide which business tasks should be customized and which should be modified based on the embedded best practices in ERP.

ERP-adopting companies tend to customize their ERP packages to some extent. Some companies use processes embedded in the ERP packages without modifications, but the majority of companies customize their packages to different extents. Most SME manufacturers in Korea use the MTO approach in which a production order is released to the manufacturing site only after a firm's demand has been received. For example, according to Pairin et al.'s (2006) research results in which 256 survey data were collected from manufacturing companies, the majority of the responding companies (70 per cent) used the MTO approach (65 per cent or more MTO), whereas only 10.2 per cent 
of the responding firms used the market-to-stock (MTS) approach (65 per cent or more MTS). SME manufacturers, in particular, often have unique manufacturing processes, and thus, their ERP packages need to be customized in most cases. For instance, a survey conducted by Jin and Chung (2001) of 82 Korean manufacturers demonstrated that most choose to customize their ERP packages upon implementation, with 8.7 per cent modifying their ERP packages by less than 10 per cent, 31.5 per cent by $11-20$ per cent, and 36.8 per cent by 21-30 per cent.

On the other hand, some researchers (Kang et al., 2008; Kim and Nam, 2001) have argued that customization should be minimized to ensure successful ERP implementation. For example, Kang et al. (2008) cited the following three reasons for minimized customization:

(1) customization is very time-consuming;

(2) customization is extremely difficult; and

(3) customization undermines the original purpose of process innovation, hindering the development of an optimized integrated system.

Additionally, Sumner (2000) insisted that companies should "re-engineer business processes to fit the package rather than trying to modify the software to fit the organization's current business processes" to implement ERP successfully. Thus, it is essential for SME manufacturers to select an ERP package that fits the existing process well to minimize customization of an ERP package. According to European surveys, the most important selection criterion for ERP is the fit between ERP and the firm's business process (Waarts et al., 2002).

Based on these previous studies, the following hypotheses were drawn to identify the correlation between customization levels and ERP success in SMEs:

H3-1. The financial performance of SME manufacturers will vary according to the level of customization of an ERP package.

H3-2. The customer performance of SME manufacturers will vary according to the level of customization of an ERP package.

H3-3. The internal process performance of SME manufacturers will vary according to the level of customization of an ERP package.

\section{Data analysis}

To collect data, a survey was carried out on SME manufacturers that have adopted and run ERP systems in Korea. Before a $t$-test was conducted to verify the hypotheses, validity and reliability tests were performed. Statistical Package for Social Sciences (SPSS) for Windows 14.0 was used for the data analysis.

\subsection{Questionnaires}

The questionnaire was developed based on relevant previous studies. A preliminary survey was carried out on five companies before the main survey, and some of the items in the questionnaire were modified. The operational definitions and measurement items of variables are described in Table I. Measurement of each question for performance was done using a five-point Likert-type scale, and the implementation of ISP and BPR and customization levels were measured by a categorical item. 


\begin{tabular}{|c|c|c|c|c|}
\hline Variable & Definition & Factor no. & Measurement item & \\
\hline \multirow[t]{6}{*}{$\begin{array}{l}\text { Performance } \\
\text { Financial } \\
\text { performance }\end{array}$} & \multirow[t]{6}{*}{ Perceptual reduced costs } & Finance 1 & $\begin{array}{l}\text { Reduced ratio of general } \\
\text { administration expenses to sales }\end{array}$ & $\begin{array}{r}\text { manufacturing } \\
\text { SMEs }\end{array}$ \\
\hline & & Finance 2 & $\begin{array}{l}\text { Reduced costs for general } \\
\text { administrative tasks (e.g. opportunity, } \\
\text { accounting) }\end{array}$ & 45 \\
\hline & & Finance 3 & $\begin{array}{l}\text { Reduced costs for management } \\
\text { coordination }\end{array}$ & \\
\hline & & Finance 4 & Reduced costs for logistics & \\
\hline & & Finance 5 & Reduced costs for business processing & \\
\hline & & Finance 6 & Reduced costs for sales & \\
\hline \multirow{5}{*}{$\begin{array}{l}\text { Customer } \\
\text { satisfaction }\end{array}$} & \multirow{5}{*}{$\begin{array}{l}\text { Perceptual customer } \\
\text { satisfaction }\end{array}$} & Customer 1 & Improved customer retention rate & \\
\hline & & Customer 2 & Improved on-time delivery rate & \\
\hline & & Customer 3 & $\begin{array}{l}\text { Reduced number of customer } \\
\text { complaints submitted }\end{array}$ & \\
\hline & & Customer 4 & Reduced response time to customers & \\
\hline & & Customer 5 & $\begin{array}{l}\text { Reduced time in claims processing } \\
\text { and handling }\end{array}$ & Table I. \\
\hline \multirow{4}{*}{$\begin{array}{l}\text { Internal } \\
\text { business } \\
\text { process }\end{array}$} & \multirow{4}{*}{$\begin{array}{l}\text { Perceptual efficient } \\
\text { improvement of internal } \\
\text { management tasks }\end{array}$} & Process 1 & Standardized business tasks & Operational \\
\hline & & Process 2 & Streamlined business procedure & definitions ar \\
\hline & & Process 3 & Accurate processing of transactions & measurement items \\
\hline & & Process 4 & Streamlined settlement of accounts & of variables \\
\hline
\end{tabular}

\subsection{Data collection}

To verify the proposed research model, questionnaires were sent either via mail or e-mail to SME manufacturers across Korea that have adopted and run ERP systems. For the data collection, the objective of this study was first explained via e-mail and telephone to relevant officials at SI (System Integrator) and consulting firms that have implemented ERP systems in SMEs, and then the list of applicable SMEs was obtained from these firms. Two hundred questionnaires were sent by mail or e-mail. Managers or higher-level officials of departments responsible for ERP implementation were asked to complete the questionnaire. One hundred and ten questionnaires were returned. Excluding those with incomplete answers, 96 questionnaires were used for the analysis.

According to the demographics of individual respondents, self-reported job titles indicated that 15 (15.6 per cent) belonged to corporate management positions such as CEO and directors, and 77 (80.2 per cent) were functional middle-management positions such as general managers and department managers. Only 4 respondents (4.2 per cent) held lower-management positions. As for the responsibilities of respondents, 41 (42.7 per cent) of them were involved in management and planning, 5 (5.2 per cent) in production, 7 (7.3 per cent) in technology, 19 (19.8 per cent) in IS and 24 (25.0 per cent) in the others. The statistical characteristics of enterprises surveyed showed that the number of their employees was 151.3 on average, and their ERP implementation had lasted for 2.3 years on average. In all, 52 responding firms implemented BPR before ERP or during the ERP introduction, and 43 firms have not implemented BPR. In ISP, 62 firms implemented it before ERP or during the ERP introduction, 25 firms have not implemented it and 9 firms that implemented it after introduction of ERP are excluded in the data analysis. 
APJIE

10,1

46

\subsection{Validity and reliability}

The factor analysis results were used to evaluate the validity of each construct. An extraction model for a principal component analysis was used to minimize information loss. A varimax-based method of the orthogonal rotation was applied to improve the solution while maintaining independence between factors. In factor analysis, factors with an eigenvalue of more than 1.0 were extracted to determine the number of factors. The results of the factor analysis, as illustrated in Table II, demonstrate high factor loading values of 0.568-0.885 for each question. To measure the reliability of each factor, an internal consistency analysis was performed on individual items using the Cronbach alpha coefficient. The coefficient was utilized to identify and remove items that undermine reliability, and thereby enhance the reliability of variables if multiple items are used to measure the same concept. As described in Table II, the reliability level was as high as 0.806-0.930, which can result from the use of measurement items verified in previous studies.

\section{Results of hypotheses test}

To verify the hypotheses, independent $t$-tests were performed to analyze differences in ERP utilization by ISP and BPR implementation, and one-way ANOVA was conducted to analyze ERP performance according to customization levels.

\subsection{Test results of ERP performance by ISP and BPR implementation}

The verification results of ERP utilization performance by ISP/BPR implementation are presented in Tables III and IV. First, the ERP performance by ISP implementation is different at a significance level of $p=0.05$ from all three BSC perspectives. Therefore, the enterprises that performed ISP are shown to have better ERP performance than those that do not.

\begin{tabular}{|c|c|c|c|c|c|c|}
\hline Factor & $\begin{array}{l}\text { Factor } \\
\text { loading }\end{array}$ & $\begin{array}{l}\text { Communality } \\
\text { estimate }\end{array}$ & Average & $\mathrm{SD}$ & Eigenvalue & $\begin{array}{c}\text { Alpha } \\
\text { (average) }\end{array}$ \\
\hline \multicolumn{7}{|c|}{ Dependent variables } \\
\hline \multicolumn{7}{|l|}{ Finance } \\
\hline Finance 1 & 0.779 & 0.748 & 3.1739 & 0.96771 & \multirow{6}{*}{8.173} & \multirow{6}{*}{0.918 (3.258) } \\
\hline Finance 2 & 0.797 & 0.703 & 3.3587 & 0.77858 & & \\
\hline Finance 3 & 0.784 & 0.807 & 3.2609 & 0.83692 & & \\
\hline Finance 4 & 0.727 & 0.623 & 3.1522 & 0.81111 & & \\
\hline Finance 5 & 0.722 & 0.734 & 3.4783 & 0.87050 & & \\
\hline Finance 6 & 0.768 & 0.748 & 3.1196 & 0.93577 & & \\
\hline \multicolumn{7}{|l|}{ Customer } \\
\hline Customer 1 & 0.807 & 0.812 & 3.3804 & 0.87508 & \multirow[t]{5}{*}{1.499} & \multirow[t]{5}{*}{0.930 (3.365) } \\
\hline Customer 2 & 0.748 & 0.806 & 3.4457 & 0.84339 & & \\
\hline Customer 3 & 0.885 & 0.868 & 3.3261 & 0.85303 & & \\
\hline Customer 4 & 0.814 & 0.778 & 3.2609 & 0.81023 & & \\
\hline Customer 5 & 0.705 & 0.786 & 3.3913 & 0.96771 & & \\
\hline \multicolumn{7}{|l|}{ Process } \\
\hline Process 1 & 0.803 & 0.721 & 3.7935 & 0.65529 & \multirow[t]{4}{*}{1.366} & \multirow{4}{*}{0.806 (3.768) } \\
\hline Process 2 & 0.686 & 0.577 & 3.5217 & 0.80491 & & \\
\hline Process 3 & 0.849 & 0.784 & 3.8587 & 0.76434 & & \\
\hline Process 4 & 0.568 & 0.543 & 3.8587 & 0.76434 & & \\
\hline
\end{tabular}

Table II.

Factor and reliability analyses of dependent variables 
In the analysis of performance differences between businesses that perform BPR and those that do not, the financial and internal process perspectives demonstrated significant differences at a significance level of $p=0.05$, while no difference was found in the customer perspective. In other words, companies that carry out BPR before or during ERP implementation show better ERP performance than those that do not from the financial and process perspectives, with the customer perspective being an exception.

\subsection{Test results of ERP performance by customization level}

To verify the differences in ERP performance by the degree of customization, the levels of customization are divided into three groups:

(1) a significant number of changes are made to the ERP module to fit the existing processes;

(2) some changes are made to the ERP module to fit the existing processes; and

(3) few or no changes are made to the ERP module to fit the existing processes.

The number of samples and average performance for each of the three groups are shown in Table V. No statistical difference was observed in the ANOVA test described in Table VI. In other words, the level of customization does not affect ERP performance.

This result is somewhat expected because SME manufacturers in Korea have a unique production process that requires customization of an ERP package. Further analysis tested how the customization and consulting costs affect ERP performance. As a customization level was not related to ERP performance, further analysis tested how the customization and consulting costs affect ERP performance. We assume that proper customization and consulting costs may affect ERP performance if ERP customization

\begin{tabular}{llcccc}
\hline Performance & ISP implementation & Average & SD & T-value & Significance \\
\hline Financial perspective & Implemented (59) & 3.349 & 0.673 & 2.599 & $0.011^{* *}$ \\
& Not implemented (25) & 2.926 & 0.702 & & \\
Customer perspective & Implemented (62) & 3.487 & 0.716 & 2.664 & $0.009^{*}$ \\
Internal process perspective & Not implemented (25) & 3.032 & 0.734 & & \\
& Implemented (61) & 3.922 & 0.522 & 4.359 & $0.000^{*}$ \\
& Not implemented (25) & 3.390 & 0.495 & &
\end{tabular}

Notes: * Significant at $p=0.01 ; * *$ significant at $p=0.05$

Table III.

$T$-Test results for ISP implementation and ERP performance

\begin{tabular}{llcccc}
\hline Performance & BPR implementation & Average & SD & T-value & Significance \\
\hline Financial perspective & Implemented (49) & 3.394 & 0.652 & 2.518 & $0.014^{*}$ \\
& Not implemented (43) & 3.040 & 0.696 & & \\
Customer perspective & Implemented (52) & 3.365 & 0.691 & 0.108 & 0.914 \\
& Not implemented (43) & 3.349 & 0.800 & & \multirow{2}{*}{ Internal process perspective } \\
& Implemented (51) & 3.922 & 0.454 & 3.180 & $0.002^{*}$ \\
& Not implemented (43) & 3.558 & 0.650 & &
\end{tabular}

Note: $*$ Significant at $p=0.05$

Table IV.

$T$-test results for BPR implementation and ERP performance 
APJIE

10,1

Classification of groups and average of ERP performance by customization level is required. To evaluate the customization and consulting costs, the statement "Consulting and customization costs were sufficient" was applied along with a five-point Likert scale from "strongly disagree" through "strongly agree". As shown in Table VII, a simple regression analysis indicated positive correlations at a significance level of $p=0.05$ for the financial and customer perspectives and at $p=0.10$ for the process perspective. This implies that consulting and customization costs are positively related to ERP performance.

\subsection{Summary of test results and implications}

Table VIII presents the summary of hypotheses results. First, implementation of ISP is shown to be a crucial factor that affects the successful adoption and utilization of ERP

\begin{tabular}{|c|c|c|c|c|}
\hline Customization level & No. of samples & $\begin{array}{c}\text { Average of } \\
\text { financial perspective }\end{array}$ & $\begin{array}{c}\text { ERP performance } \\
\text { Average of } \\
\text { customer perspective }\end{array}$ & $\begin{array}{l}\text { Average of internal } \\
\text { process perspective }\end{array}$ \\
\hline Significant changes & 31 & 3.384 & 3.368 & 3.233 \\
\hline Some changes & 39 & 3.808 & 3.390 & 3.243 \\
\hline Few or no changes & 25 & 3.604 & 3.360 & 3.234 \\
\hline Total & 95 & 3.766 & 3.375 & 3.238 \\
\hline
\end{tabular}

\begin{tabular}{|c|c|c|c|c|c|}
\hline Performance & $\begin{array}{l}\text { Sum of } \\
\text { squares }\end{array}$ & Df & $\begin{array}{c}\text { Mean } \\
\text { square }\end{array}$ & $F$-value & Significance \\
\hline \multicolumn{6}{|c|}{ Financial perspective } \\
\hline Between groups & 0.016 & 2 & 0.008 & 0.014 & 0.986 \\
\hline Within groups & 50.484 & 92 & 0.549 & & \\
\hline Total & 50.499 & 94 & & & \\
\hline \multicolumn{6}{|c|}{ Customer perspective } \\
\hline Between groups & 0.860 & 2 & 0.430 & 1.233 & 0.296 \\
\hline Within groups & 31.741 & 91 & 0.349 & & \\
\hline Total & 32.601 & 93 & & & \\
\hline \multicolumn{6}{|c|}{ Internal process perspective } \\
\hline Between groups & 0.002 & 2 & 0.001 & 0.002 & 0.998 \\
\hline Within groups & 44.866 & 89 & 0.504 & & \\
\hline Total & 44.868 & 91 & & & \\
\hline
\end{tabular}

Table VI.

ANOVA test results for customization level

\begin{tabular}{llccrcc}
\hline Performance & Items & Coefficient & $\mathrm{SD}$ & $T$-value & $R^{2}$ & Significance \\
\hline Financial perspective & (Constant) & 2.333 & 0.263 & 8.877 & 0.123 & $0.001^{*}$ \\
& Cost & 0.297 & 0.083 & 3.577 & & \\
Customer perspective & (Constant) & 2.581 & 0.281 & 9.192 & 0.082 & $0.005^{*}$ \\
Internal process perspective & Cost & 0.255 & 0.088 & 2.889 & & \\
& (Constant) & 3.346 & 0.230 & 14.521 & 0.037 & $0.061^{* *}$ \\
& Cost & 0.138 & 0.072 & 1.900 & &
\end{tabular}

Table VII.

Correlation between consulting/ customization costs and ERP performance

Notes: * Significant at $p=0.01 ; * *$ significant at $p=0.1$ 


\begin{tabular}{|c|c|c|c|}
\hline Area & Hypothesis & Result & \\
\hline \multirow[t]{3}{*}{ ISP } & $\begin{array}{l}\text { H1-1. SME manufacturers performing ISP before or upon ERP } \\
\text { implementation will show better financial performance than those that } \\
\text { do not }\end{array}$ & Accepted & $\begin{array}{r}\text { manufacturing } \\
\text { SMEs }\end{array}$ \\
\hline & $\begin{array}{l}\text { H1-2. SME manufacturers performing ISP before or upon ERP } \\
\text { implementation will show better customer performance than those that } \\
\text { do not }\end{array}$ & Accepted & \\
\hline & $\begin{array}{l}\text { H1-3. SME manufacturers performing ISP before or upon ERP } \\
\text { implementation will show better internal process performance than } \\
\text { those that do not }\end{array}$ & Accepted & \\
\hline \multirow[t]{3}{*}{ BPR } & $\begin{array}{l}\text { H2-1. SME manufacturers performing BPR before or upon ERP } \\
\text { implementation will show better financial performance than those that } \\
\text { do not }\end{array}$ & Accepted & \\
\hline & $\begin{array}{l}\text { H2-2. SME manufacturers performing BPR before or upon ERP } \\
\text { implementation will show better customer performance than those that } \\
\text { do not }\end{array}$ & Rejected & \\
\hline & $\begin{array}{l}\text { H2-3. SME manufacturers performing BPR before or upon ERP } \\
\text { implementation will show better internal process performance than } \\
\text { those that do not }\end{array}$ & Accepted & \\
\hline \multirow[t]{3}{*}{$\begin{array}{l}\text { Customization } \\
\text { level }\end{array}$} & $\begin{array}{l}\text { H3-1. Financial performance of SME manufacturers will vary according } \\
\text { to the level of customization of an ERP package }\end{array}$ & Rejected & \\
\hline & $\begin{array}{l}\text { H3-2. Customer performance of SME manufacturers will vary according } \\
\text { to the level of customization of an ERP package }\end{array}$ & Rejected & Table \\
\hline & $\begin{array}{l}\text { H3-3. Internal process performance of SME manufacturers will vary } \\
\text { according to the level of customization of an ERP package }\end{array}$ & Rejected & $\begin{array}{r}\text { Summary of } \\
\text { hypothesis results }\end{array}$ \\
\hline
\end{tabular}

systems by SME manufacturers. This result is consistent with the argument that "strategic understanding is valuable" for the successful implementation of ERP by Muscatello et al. (2003). ISP has been used primarily by large companies to formulate master plans for the implementation of information systems, but more recently, ISP has been increasingly utilized by SMEs as well. The empirical study performed as a part of this study demonstrates that, given the recent increase in the volumes of data to be managed by manufacturers and the growing importance of information technology management, ISP needs to be implemented to systematically manage information systems. Providing a blueprint for corporate informatization, ISP will be helpful for securing financial resources and pursuing the implementation process phase by phase when introducing a system, such as ERP, that requires a relatively large investment.

Second, implementation of BPR before or upon ERP adoption is positively correlated to ERP performance, as demonstrated in the results of previous studies on the BPR and ERP performances of large businesses. This implies that BPR needs to be carried out to successfully implement ERP systems in SMEs as well.

Third, the vast majority of the studies (Kang et al., 2008; Kim and Nam, 2001; Sumner, 2000) conducted has recommended minimizing customization of ERP packages as much as possible, and recommended changing current business processes to fit the ERP system. However, previous studies have found that Korean SMEs prefer customization. For instance, Jin and Chung (2001) indicate that 77 per cent of 82 businesses surveyed modified their ERP packages. A survey of 74 companies by Choi and Hwang (2007) also shows that 100 per cent and 89.2 per cent of those surveyed performed customization of "script modification" and "database 

customization costs. This is largely because of the unique processes utilized by SME manufacturers, as they need to produce various types of products in response to differing demands from their clients. This indicates that customization is necessary for SME manufacturers, which use unique processes in contrast to the standardized business processes of larger enterprises. This result is consistent with the findings of Gattiker and Goodhue (2002). In their study, 70 manufacturing firms were surveyed to discover how ERP-driven process changes affect ERP impacts. The researchers concluded that not all process changes affect ERP performance, but business processes that contribute to business strategy are related to ERP performance. In this regard, these results suggest that seeking adequate consulting services and making sufficient investments for customization will improve the performance of ERP in SMEs.

Fourth, the hypothesis result demonstrates that BPR implementation influences internal processes and financial performance, while no significant statistical difference is found from the customer perspective. This reflects how the very nature of BPR focuses on process improvement.

\section{Conclusions}

\subsection{Contributions to research and practice}

The results of this paper contribute to both research and practice. Little research on the relationships between the ISP and BPR implementation and firm performance has been carried out in the context of manufacturing SMEs. Our focus on ISP and BPR in manufacturing SMEs adds to the body of ERP performance research (Shiau et al., 2009; Gefen and Ragowsky, 2005; Liang and Xue, 2004; Newman and Zhao, 2008). For researchers, our findings showing the importance of ISP and BPR, even for manufacturing SMEs, prompt future research. For example, how ISP affects the success of ERP and is there any relationship between ISP and BPR on ERP? A more elaborate and comprehensive conceptual model can be built to further this stream of research. The research also informs practice. First, it is empirically shown that ISP and BPR implementation is valuable for SME manufacturers. ISP and BPR have generally been carried out by larger businesses, but the growing importance of information management and greater complexities require more systematic management of information technology and strenuous efforts for process restructuring in SMEs. Second, as shown in the survey result of this study that 70 out of 95 firms carried out customization of ERP package, some degree of customization is necessary for Korea SME manufacturers. So, adequate investments need to be made to seek consulting services and pursue appropriate customization. Third, the findings of this research provide a reference for managers considering implementation of ERP in SMEs.

\subsection{Limitations and future research directions}

This study, consisting of questionnaires answered by 96 SMEs manufacturers that have adopted ERP systems, has identified differences in the ERP performance of SME manufacturers according to ISP and BPR implementations and the levels of customization. The results of this study suggest that ISP and BPR implementation are positively correlated to ERP performance. The level of customization, however, does not 
influence ERP performance, while consulting and customization costs have positive impacts on it. This means that the ERP packages for SMEs manufacturers could be customized to some extent, given their unique business processes.

This study also has some limitations. First, this study compared companies pursuing BPR and those that do not, but the results may differ according to the success and failure of BPR implementation. Even BPR-implementing businesses may present poor ERP performance if they fail to fully implement BPR. Second, potential confounding variables, including top management support, the ERP consultants' capability and users' participations and training, may contribute to the impact of ERP. Third, this study measured the level of customization for the whole ERP systems and not for individual modules of ERP systems. In addition, customization methods (e.g. bolt-on software, exit routines or modifications to ERP source code) may affect the impact of ERP. For further research, it may be worthwhile to investigate ERP performance based on the level of customization of each module. This may provide more detailed implications for practitioners. Fourth, the sample is limited to the manufacturing SMEs. Future studies can investigate the importance of ISP, BPR and customization levels for non-manufacturing sectors of SMEs. Fifth, this study was conducted in the Korean manufacturing firms; thus, the generalization of the study results to other countries is not warranted.

\section{References}

Aloini, D., Dulmin, R. and Mininno, V. (2007), "Risk management in ERP project introduction: review of the literature", Information \& Management, Vol. 44 No. 6, pp. 547-567.

Ansari, S. (2000), Business Processing Reengineering, McGraw-Hill, New York, NY.

Bernroider, E.W.N. (2008), "IT governance for enterprise resource planning supported by the DeLone-McLean model of information systems success", Information \& Management, Vol. 45 No. 5, pp. 257-269.

Buonanno, G., Faverio, P., Pigni, F., Ravarini, A., Sciuto, D. and Tagliavini, M. (2005), "Factors affecting ERP system adoption", Journal of Enterprise Information Management, Vol. 18 No. 4, pp. 384-426.

Choi, M.J. and Hwang, H.Y. (2007), "The impact of process innovation and customization on ERP performance", Business Education, Vol. 47, pp. 351-378.

Choi, M.G., Kim, K.J., Hwang, W.J. and Kim, B.G. (2011), “A study on the quality of ERP system affecting satisfaction and job performance", Journal of the Korea Industrial Information Systems Research, Vol. 16 No. 3, pp. 89-99.

Choi, Y.E., Park, J.P. and Lee, U.K. (2013), “A study on the factors affecting government-support ERP systems adoption for SMEs”, The Journal of Information Systems, Vol. 22 No. 4, pp. 1-22.

Costa, G. and Gianecchini, M. (2006), "Tecnologia, cambiamento organizzativo e competitivita Il ruolodei sistemi informativi integrati”, Paper presented to the workshop WOA 2006 Organizzazione, Regolazione e Competitivita, 2-3 February, Fisciano, Salerno.

DeLone, W.H. and McLean, E.R. (1992), "Information systems success: the quest for the dependent variable", Information Systems Research, Vol. 3 No. 1, pp. 61-95.

DeLone, W.H. and McLean, E.R. (2003), "The DeLone and McLean model of information systems success: a ten-year update”, Journal of Management Information Systems, Vol. 19 No. 4, pp. 9-30.

Deo, Z. (2010), “A strategy implementation framework for international SME's”, Asia Pacific Journal of Innovation and Entrepreneurship, Vol. 4 No. 1, pp. 23-65. 
APJIE

10,1

Elzinga, J., Gulledge, T.R. and Lee, C.Y. (1999), Business Process Engineering: Advancing the State of Art, Kluwer Academic Publishers, Boston, MA.

Garengo, P., Biazzo, S. and Bititci, U. (2005), "Performance measurement systems in SMEs: a review for a research agenda”, International Journal of Management Reviews, Vol. 7 No. 1, pp. 25-47.

Gattiker, T.F. and Goodhue, D.L. (2002), "Software driven changes to business processes: an empirical study of impacts of enterprise resource planning systems at the local level", International Journal of Production Research, Vol. 40 No. 18, pp. 4799-4814.

Gefen, D. and Ragowsky, A. (2005), "A multi-level approach to measuring the benefits of an ERP system in manufacturing firms", Information Systems Management, Vol. 22 No. 1, pp. 18-25.

Hammer, M. (1999), "Reengineering at net speed - the first wave of business process revisions took about a decade; the new wave is taking less than half that time", InformationWeek, p. 176.

Holsapple, C.W. and Sena, M.P. (2005), "ERP plans and decision-support benefits", Decision Support Systems, Vol. 38 No. 4, pp. 575-590.

Hong, S., Choi, Y. and Hwang, S. (2005), "The impact of ERP implementation on the organizational performance in manufacturing firms", The Korean Association of Small Business Studies, Vol. 27 No. 4, pp. 1-20.

Irani, Z. and Love, P. (2008), Evaluating Information Systems: Public and Private Sector, Butterworth-Heinemann.

Jang, K., Kim, J. and Lee, J. (2000), “A study on success factors of ERP system”, Korea International Accounting Review, Vol. 3 No. 4, pp. 87-101.

Jin, C.D. and Chung, G.S. (2001), "An empirical study on impact of ERP (enterprise resource planning) system on performance", Proceedings of the Korea Association of Information Systems, pp. 111-125.

Jin, C.H., Kwon, Y.J., Cui, J., Lee, S.H. and Kim, S.Y.(2012), “A study of ERP construction strategies by system factors: based on case studies of Korea and China firms", Journal of the Korea Industrial Information Systems Research, Vol. 17 No. 3, pp. 69-81.

Kang, S., Park, J. and Yang, H. (2008), "ERP alignment for positive business performance: evidence from Korea's ERP market”, Journal of Computer Information Systems, Vol. 48 No. 4, pp. 25-38.

Kaplan, R.S. and Norton, D.P. (1992), "The balanced scorecard - measures that drive performance", Harvard Business Review, Vol. 70 No. 1, pp. 71-79.

Kim, T.W. and Nam, Y.S. (2001), "The study on the impact of ERP implementation on performance”, The Journal of MIS Research, Vol. 10 No. 1, pp. 61-79.

Kim, Y. and Park, J. (2006), "Critical success factors and user performance analysis on BPR based ERP systems", Journal of Korea Management Education, Vol. 42 No. 4, pp. 277-294.

Kohli, R. and Hoadley, E. (2006), "Towards developing a framework for measuring organizational impact of IT-enabled BPR: case studies of three firms", Database for Advances in Information Systems, Vol. 37 No. 1, pp. 40-58.

Kotha, S. and Swamidass, P.M. (2000), "Strategy, advanced manufacturing technology and performance: empirical evidence from US manufacturing firms", Journal of Operations Management, Vol. 18, pp. 257-277.

Larsen, M. and Myers, M. (1999), "When success turns to failure: a package driven business process re-engineering project in the financial services industry", Journal of Strategic Information Systems, Vol. 8, pp. 395-417. 
Lee, J., Lim, J. and Jung, C. (2008), “A study on the success model of ERP systems from the end users' perspective: focused on K public corporation”, Journal of the Korea Industrial Information Systems Research, Vol. 13 No. 4, pp. 35-55.

Lee, J., Siau, K. and Hong, S. (2003), "Enterprise Integration with ERP and EAI”, Communications of the ACM, Vol. 46 No. 2, pp. 54-60.

Lee, S.H., Sawng, Y.W., Lee, Y.W. and Park, S.Y. (2014), "Incremental and radical innovation in new product development: comparison of large corporations and small-to medium-sized enterprises", Asia Pacific Journal of Innovation and Entrepreneurship, Vol. 8 No. 2, pp. 23-42.

performance in manufacturing

SMEs

53

Liang, H. and Xue, Y. (2004), "Coping with ERP-related contextual issues in SMEs: a vendor's perspective", Strategic Information Systems, Vol. 13 No. 4, pp. 399-415.

Light, B. (2001), "The maintenance implications of the customization of ERP software", Journal of Software Maintenance and Evolution: Research and Practice, Vol. 13, pp. 415-429.

Lin, W.T., Chen, S.C., Lin, M.Y. and Wu, H.H. (2006), "A study on performance of introducing ERP to semiconductor related industries in Taiwan", The International Journal of Advanced Manufacturing Technology, Vol. 29 Nos 1/2, pp. 89-98.

Markus, M.L., Tanis, C. and Fenema, P.C.V. (2000), "Multisite ERP implementations", Communications of the ACM, Vol. 43 No. 4, pp. 42-46.

Martinsons, M.G. (2004), "ERP in China: one package, two profiles", Communications of the ACM, Vol. 47, pp. 65-68.

Muscatelli, A., Tirelli, P. and Trecroci, C. (2003), "The interaction of fiscal and monetary policies: some evidence using structural models”, Journal of Macroeconomics, Vol. 15, pp. 120-135.

Muscatello, J.R., Small, M.H. and Chen, I.J. (2003), "Implementing enterprise resource planning (ERP) systems in small and midsize manufacturing firms", International Journal of Operations \& Production Management, Vol. 23 No. 8, pp. 850-871.

Nah, F., Islam, Z. and Tan, M. (2007), "Empirical assessment of factors influencing success of enterprise resource planning implementations", Journal of Database Management, Vol. 18 No. 4, pp. 26-50.

Newman, M. and Zhao, Y. (2008), "The process of enterprise resource planning implementation and business process reengineering: tales from two Chinese small and medium-sized enterprises", Information Systems Journal, Vol. 18, pp. 405-426.

O'Leary, D. (2000), Enterprise Resource Planning Systems: Systems, Life Cycle, E-commerce and Risk, Cambridge University Press, Cambridge.

Pairin, K., Hong, S. and Lee, J. (2006), "Enterprise resource planning survey of Korean manufacturing firms", Management Research News, Vol. 29 No. 12, pp. 820-837.

Park, H.S., Lee, Y.W. and Park, S.Y. (2012), "R\&D types and investment of SMEs according to CEOs' gender types in Korea”, Asia Pacific Journal of Innovation and Entrepreneurship, Vol. 6 No. 1, pp. 33-50.

Rosemann, M. (1999), "Measuring the performance of ERP software-a balanced scorecard approach", Proceedings in 773th Australasian Conference on Information Systems, pp. 773-784.

Sammon, D. and Adam, F. (2010), "Project preparedness and the emergence of implementation problems in ERP projects", Information \& Management, Vol. 47 No. 1, pp. 1-8.

Schniederjans, M. and Kim, E. (2005), "Relationship of student undergraduate achievement and personality characteristics in a total web-based environment: an empirical study", Decision Sciences Journal of Innovative Education, Vol. 3 No. 2, pp. 205-221. 
APJIE

10,1

Schubert, P., Kummer, M. and Leimstoll, U. (2006), "Legal requirements for the personalization of commercial internet applications in Europe", Journal of Organizational Computing \& Electronic Commerce, Vol. 16 Nos 3/4, pp. 203-221.

Sethi, V. and King, W.R. (1998), Organizational Transformation through Business Process Reengineering: Appling the Lessons Learned, Prentice-Hall PTR, Upper Saddleback River, NJ.

Shiau, W.L., Hsu, P.Y. and Wang, J.Z. (2009), "Development of measures to assess the ERP adoption of small and medium enterprises", Journal of Enterprise Information Management, Vol. 22 Nos 1/2, pp. 99-118.

Sumner, M. (2000), "Risk factors in enterprise-wide ERP projects", Journal of Information Technology, Vol. 15 No. 4, pp. 317-327.

Thong, J.Y.L., Chee-Sing, Y. and Raman, K.S. (1996), "Top management support, external expertise and information systems implementation in small businesses", Information Systems Research, Vol. 7 No. 2, pp. 248-267.

Velcu, O. (2007), "Exploring the effects of ERP systems on organizational performance: evidence from Finnish companies", Industrial Management \& Data Systems, Vol. 107 No. 9, pp. 1316-1334.

Waarts, E., van Everdingen, Y.M. and van Hillegersberg, J. (2002), "The dynamics of factors affecting the adoption of innovations", The Journal of Product Innovation Management, Vol. 19 No. 6, pp. 412-423.

Yun, J.H. and Jung, W.Y. (2013), "Open innovation of SMEs in manufacturing from OI structure model”, Asia Pacific Journal of Innovation and Entrepreneurship, Vol. 7 No. 1, pp. 23-35.

\section{Further reading}

Federici, T. (2009), "Factors influencing ERP outcomes in SMEs: a post-introduction assessment", Journal of Enterprise Information Management, Vol. 22 Nos 1/2, pp. 81-98.

Van der Aalst, W.M.P. and Weijters, A.J.M.M. (2004), "Process mining: a research agenda", Computers in Industry, Vol. 53 No. 3, p. 231.

Corresponding author

Jong-Weon Kim can be contacted at: jokim@deu.ac.kr

For instructions on how to order reprints of this article, please visit our website:

www.emeraldgrouppublishing.com/licensing/reprints.htm

Or contact us for further details: permissions@emeraldinsight.com 